\title{
E-LEARNING SEBAGAI EVOLUSI PROSES PEMBELAJARAN DI ERA MASYARAKAT INFORMASI
}

\author{
Oleh \\ Putu Kussa Laksana Utama \\ Institut Hindu Dharma Negeri Denpasar \\ kuasa.laksana@gmail.com
}

Diterima 14 Desember 2016, direvisi 30 Januari 2017, diterbitkan 28 Pebruari 2017

\begin{abstract}
Education is a important thing in a human civilization history. The progress of a civilization is mostly determined by education as a main factor. Throughout the history of human civilization, there were so many learning methods has been invented such as discussion method, discourse method, group teaching, and technology-supported learning method. The fast development of Information and Communication Technology (ICT) in the era of information society has facilitated all of knowledge seekersnowdays to learn something better and better.E-Learning as a implementation of ICT in education domain takes the role as a education media which provide education content so that the students are able to access it times infinity.
\end{abstract}

Keyword: Education, Education Technology, E-Learning

\section{PENDAHULUAN}

Pendidikan tidak dapat dipungkiri merupakan salah satu tolak ukur kemajuan suatu bangsa. Bangsa yang maju merupakan bangsa yang memperhatikan kualitas pendidikan warga negaranya. Menurut penelitian yang dilakukan oleh Philip Stevens dan Martin Weale (2003) bahwa tingkat pendidikan memiliki pengaruh pada pertumbuhan ekonomi. Penelitian tersebut menggunakan data dari awal abad ke 20-an. Tingkat pendidikan yang tinggi akan mempengaruhi pendapatan per kapita individu suatu negara dan memiliki dampak langsung terhadap pertumbuhan ekonomi nasional. Hal yang serupa juga didukung oleh penelitian yang dilakukan oleh Philippe Aghion, dkk (2009) bahwa tingkat pendidikan memiliki pengaruh yang cukup signifikan terhadap income per kapita suatu negara. Oleh karena itu sangat penting bagi suatu negara untuk lebih memperhatikan tingkat pendidikan masyarakatnya. Negara harus menjamin keberlangsungan pendidikan mulai dari level yang paling dasar hingga pendidikan tinggi. Selain itu negara juga diharapkan dapat memberikan dukungan dalam hal menciptakan iklim belajar yang kondusif, menyediakan fasilitas-fasilitas yang dibutuhkan oleh peserta didik, dan berperan serta dalam memotivasi peserta didik.

Pendidikan berbasis ICT (Information Communication Technology) merupakan sebuah sarana yang tepat bagi negara-negara berkembang dalam mengejar ketertinggalannya dari negara-negara maju. ICT mampu menjembatani komunikasi antar individu dari berbagai negara, sehingga proses sharing informasi menjadi lebih mudah. ICT juga

E-learning Sebagai Evolusi Proses Pembelajaran 
membawa paradigma baru dimana ilmu pengetahuan tidak lagi bisa dimonopoli oleh negara-negara maju akan tetapi sebaliknya memberikan kesempatan bagi seluruh manusia dari berbagai penjuru dunia untuk mengaksesnya. Pemanfaatan ICT di bidang pendidikan juga merupakan suatu hal yang sifatnya urgent di masa kini. Dengan konsep sharing informasi tanpa batas dan waktu yang ditawarkan, ICT mampu menciptakan sebuah iklim pembelajaran yang lebih kompetitif, lebih dinamis dan lebih menarik dimana hal tersebut akan mampu meningkatkan mutu pendidikan itu sendiri.

Perkembangan Teknologi yang sangat pesat dewasa ini memiliki pengaruh yang cukup signifikan juga terhadap proses belajar mengajar. Teknologi mampu mengurangi gap level pendidikan antara negara yang satu dengan yang lain. Selain itu teknologi juga mampu meningkatkan kualitas pengajaran itu sendiri. Di berbagai negara bahkan penerapan teknologi untuk membantu proses belajar mengajar sudah dimulai sejak usia dini.

\section{PEMBAHASAN}

\section{a. Definisi Pendidikan}

Pendidikan secara etimologi berasal dari kata Yunani yaitu Paedagogie. Kata paedagogie ini berasal dari kata paedagogia yang berarti pergaulan dengan anak. Kata "paida" merujuk kepada kanak-kanak, sehingga terdapat perbedaan istilah yang digunakan yaitu pedagogi (mengajar anakanak) dan andragogi (mengajar orang dewasa) (Sukardjo, 2009). Jadi kata pedagogi tersusun atas dua buah kata yaitu "peda" atau "paid" yang artinya anak-anak, dan "ogogos" yang berarti membina atau membimbing. Sehingga konsep pendidikan yang dilaksanakan selama ini memiliki makna harafiah seni mengajar atau seni mendidik anak-anak (Muis Sad Imam, 2004). Pendidikan dimulai di keluarga atas anak (infant) yang belum mandiri, kemudian diperluas di lingkungan komunitas sekitar (milieu), lembaga prasekolah, persekolahan formal dan lingkungan yang lain mulai dari lingkungan kelompok kecil sampai besar (Rasyidin, 2007).

Sepanjang sejarah peradaban manusia ada berbagai pendapat dan definisi pendidikan yang dikemukakan oleh para ahli. John Dewey berpendapat bahwa pendidikan merupakan proses dalam hidup yang diperoleh dari pengalaman-pengalaman selama hidup ("The Philosophy of John Dewey", 1981). Pendidikan menurut John Dewey adalah bentuk negasi dari pola pendidikan yang umum dijumpai di tengahtengah masyarakat dimana para peserta didik hanya duduk pasif menerima materi sementara pendidik secara terus menerus memberi ceramah. Seorang peserta didik harus ditempatkan pada suatu lingkungan sosial agar bisa berinteraksi secara sosial. Dari interaksi yang tecipta tersebut maka timbulah pengalaman-pengalaman yang merupakan fondasi dasar sesuai dngan konsep pendidikan yang diajukan oleh John Dewey. Frederick J. Mc Donald dalam bukunya yang berjudul "Educational Psychology" berpendapat bahwa pendidikan adalah suatu aktivitas yang bertujuan untuk mengubah perilaku dari manusia atau peserta didik (Mc Donald, 1965). Sedangkan menurut Ki Hadjar Dewantara, pendidikan adalah suatu tuntunan di dalam hidup tumbuhnya anak-anak (Dewantara II, 1994). Tuntunan yang dimaksud adalah pendidikan merupakan hal yang menuntun segala kekuatan kodrat yang ada pada peserta didik agar menjadi manusia dan anggota masyarakat dapat mencapai keselamatan dan kebahagiaan hidup yang setinggi-tingginya.

\section{b. Tujuan Pendidikan}

Tujuan menggambarkan sebuah visi dari sebuah tindakan yang dilakukan. Tujuan juga menjelaskan sesuatu hal yang ingin dicapai dari sebuah tindakan. Dengan mengetahui tujuan maka langkah-langkah yang harus ditempuh 
juga semakin jelas. Demikian juga dengan tujuan dari pendidikan yang mengambarkan mengenai pencapaian yang nanti diperoleh dari sebuah pendidikan.

Menurut Plato, tujuan pendidikan yang sesungguhnya adalah penyadaran terhadap self-knowing dan self-realization kemudian inquiry dan reasoning dan logic. Jadi tujuan dari pendidikan yang dimaksud oleh Plato adalah memberikan penyadaran terhadap sesuatu yang diketahuinya, kemudian pengetahuan tersebut harus direalisasikan sendiri dan selanjutnya meneliti serta menemukan hubungan kausal alasan dan alur pikirnya. Sementara menurut filsafat lain seperti Aristoteles menyebutkan bahwa tujuan pendidikan penyadaran terhadap selfrealization, yaitu kekuatan efektif (virtue) kekuatan untuk menghasilkan (efficacy) dan potensi untuk mencapai kebahagian hidup melalui kebiasaan dan kemampuan berpikir rasional (Sukardjo, 2009). Sedangkan menurut Negara Kesatuan Indonesia melalui UndangUndang Nomor 20 tahun 2003 tentang Sistem Pendidikan Nasional pasal 3 menyatakan bahwa tujuan pendidikan nasional adalah mengembangkan potensi peserta didik agar menjadi manusia yang beriman dan bertakwa kepada Tuhan Yang Maha Esa, berakhlak mulia, sehat, berilmu, cakap, kreatif, mandiri, dan menjadi warga negara yang demokratis serta bertanggung jawab. Berdasarkan Undang-Undang tersebut jelas bahwa terdapat tanggung jawab moral antara masyarakat kepada negara dan Tuhan Yang Maha Esa.

\section{c. Teori-Teori Pendidikan}

Ada beragam teori pendidikan yang berkembang sejauh ini. Teori pendidikan adalah seperangkat konsep-konsep tentang pendidikan yang bermula dari asumsi-asusi mendasar mengenainya. Teori ini berangkat dari konsep mengenai manusia, baik sebagai peserta didik maupun pendidik, dan sekaligus alat dan media yang diperlukan untuk pendidikan itu sendiri. Ada beberapa teori pendidikan yang cukup dikenal yaitu, Behaviorisme, Konstruktivisme Kognitif, dan Konstruktivisme Sosial.

Teori Behaviorisme adalah teori yang menyatakan bahwa proses belajar adalah suatu perubahan perilaku yang merupakan respon dari sebuah stimulus (Skinner, 1976). Teori behaviorisme pada awalnya merupakan sebuah penolakan terhadap psikologi introspektif yang berkembang pada awal abad 20 Masehi. Menurut Skinner, metode psikologi introspektif cenderung subyektif dan tidak bisa diukur dalam mengamati sebuah obyek. Namun untuk mengamati dan mengukur secara obyektif halhal yang muncul dalam pikiran sangatlah mustahil, oleh karena itu diperlukanlah suatu teori ilmiah yang hanya mempertimbangkan indikator-indikator yang dapat diobservasi saja seperti respon dan stimulus. Dalam kaitannya dengan proses belajar, seseorang dianggap telah belajar apabila dapat menunjukan perubahan tingkah laku. Stimulus dalam proses belajar dapat berupa input yang guru berikan kepada peserta didik, sedangkan respon adalah hasil yang ditunjukan oleh peserta didik ketika menerima stimulus (Skinner, 1976).

Teori konstruktivisme merupakan teori yang menyatakan bahwa seorang peserta didik dapat membangung pengetahuan dan pemahaman tentang hal-hal di sekelilingnya melalui pengalaman yang diperolehnya. Teori konstruktivisme dapat dikelompokan menjadi dua bagian, yaitu teori konstruktivisme kognitif dan teori konstruktivisme sosial. Teori konstruktivisme kognitif adalah teori yang menyatakan bahwa pengetahuan yang diperoleh dalam proses belajar dibangun berdasarkan pengalaman yang diperoleh dari proses belajar sebelumnya. Peserta didik secara aktif harus membangung pengetahuan baru berdasarkan pengalaman yang telah dimiliki sebelumnya, sedangkan tugas pendidik adalah menyediakan sumber daya yang diperlukan dan membimbing peserta didik (Perry, 1999). Teori 
konstruktivisme sosial merupakan varian dari teori konstruktivisme kognitif yang menekankan pada keterlibatan aspek sosial sebagai stimulus dalam membangung pengetahuan kognitif. Menurut Vygotsky (1978), aspek-aspek sosial seperti bahasa dan budaya memiliki peran yang sangat penting dalam pengembangan kecerdasan manusia. Teori konstruktivisme sosial diimplementasikan dalam bentuk collaborative learning atau pembelajaran beregu dimana peserta didik membentuk kelompok-kelompok belajar dengan satu atau beberapa topik pembahasan dan pendidik bertugas menjadi moderator dalam kelompok tersebut (Vygotsky, 1978).

\section{d. Metode Pembelajaran}

Ada banyak metoda pembelajaran yang dikenal dalam dunia pendidikan. Metoda pembelajaran tersebut memiliki kelebihan dan kekurangan masing-masing, beberapa diantaranya adalah:

\section{1) Metode Ceramah}

Metoda ceramah merupakan metoda menerangkan materi pembelajaran secara lisan kepada peserta didik (Syah M.,2000). Metoda ini biasanya diterapkan pada kelompok peseta didik dalam jumlah yang besar. Melalui metoda ceramah pendidik dapat mendorong munculnya inspirasi bagi peserta didik. Metoda ini amat cocok untuk penyampaian bahan belajar yang berupa informasi. Djamarah (2000) menjelaskan bahwa metoda ceramah apabila dilakukan dalam waktu yang lama dapat membuat jenuh peserta didik.

2) Metode Diskusi

Metoda diskusi merupakan metoda belajar yang melibatkan dua orang peserta atau lebih untuk melakukan interaksi, saling bertukan pendapat, atau saling mempertahankan pendapat dalam pemecahan masalah (McKeachi, 1999). Metoda diskusi menuntut peran aktif dari peserta didik maupun pendidik itu sendiri. Keunggulan dari metoda diskusi adalah mampu meningkatkan anak dalam pemahaman konsep dan keterampilan memecahkan masalah, namun dari aspek kecepatan transfer pengetahuan jauh lebih lambat apabila dibandingkan dengan metoda ceramah.

\section{3) Metode Resitasi}

Metode resitasi adalah suatu aktivitas pembelajaran yang dilakukan dengan jalan memberi tugas khusus kepada peserta didik untuk mengerjakan sesuatu di luar jam pelajaran. Pelaksanaannya bisa dimana saja, di rumah, di perpustakaan, atau di laboratorium, dan hasilnya dipertanggungjawabkan kepada pendidik. Pemberian tugas dapat mendorong siswa untuk untuk belajar lebih banyak, baik di kelas maupun di luar kelas. Kelemahan dari metoda ini adalah sulitnya melakukan kontrol terhadap pekerjaan peserta didik (Alipandie, 1984).

\section{4) Metode Eksperimental}

Metode eksperimen adalah suatu cara mengajar dimana siswa melakukan suatu percobaan tentang sesuatu hal, mengamati prosesnya serta menuliskan hasil percobaanya, kemudian hasil pengamatan itu disampaikan ke kelas dan dievaluasi oleh guru (Roestiyah, 2001). Aktivitas ini memberikan keunggulan yaitu membuat peserta didik lebih memahami obyek yang sedang dipelajarinya karena terlibat langsung dan merasakan langsung dalam proses 
pembelajaran yang dijalaninya. Namun untuk melaksanakan metode ini dibutuhkan peralatan dan perlengkapan yang memadai.

5) Metode Computer Supported Collaborative Learning (CSCL)

Metode ini merupakan sebuah pendekatan pendidikan dimana peserta didik berkumpul dalam sebuah media sosial berbasis internet dengan bantuan komputer. Komponen penting dalam metode pembelajaran ini adalah penggunaan komputer dan internet sebagai alat bantu belajar. Melalui bantuan komputer dan internet lingkungan proses belajar mengajar dapat dibuat sedinamis mungkin tanpa terikat dengan variable ruang, jarak, dan waktu (Hernandez-Seles, dkk,2014).

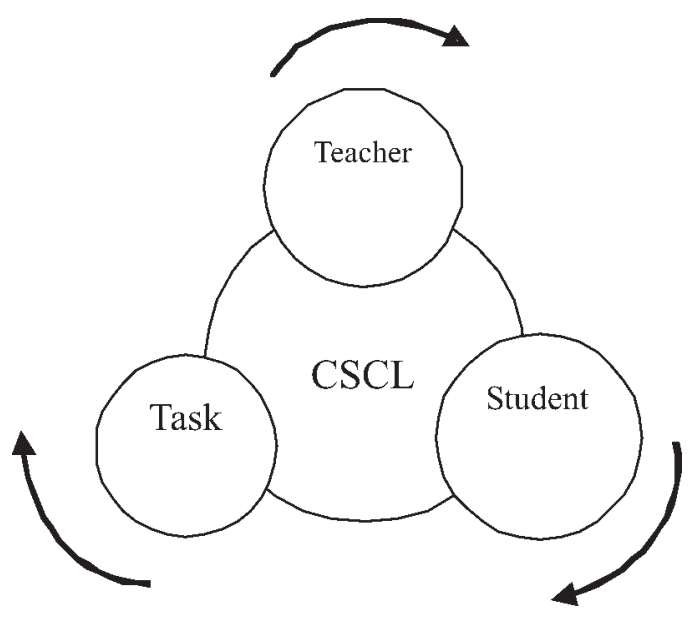

Gambar 1. Diagram konsep CSCL (Hernandez-Selles, dkk, 2014)

\section{e. Informasi}

Konsep informasi tidak dapat dilepaskan dari konsep data. Data merupakan sebuah "raw fact" atau fakta mentah. Fakta mentah yang dimaksud adalah sebuah realita yang tidak terikat atau ditempatkan pada suatu konteks tertentu. Sedangkan informasi adalah sebuah data yang sudah ditempatkan pada sebuah konteks (Floridi, 2010).

Dengan semakin banyaknyainformasi yang tersebar di masyarakat memungkinkan lebih banyak orang yang berpengetahuan lebih dimana umumnya pengetahuan-pengetahuan tersebut biasanya hanya dimiliki oleh kelompok-kelompok professional dan akademisi saja. Selain itu dengan kemajuan teknologi informasi dan komunikasi menyebabkan jarak antar kelompok masyarakat dapat diminimalisir. Dengan kemajuan teknologi informasi dan komunikasi, informasi dapat disampaikan dalam berbagai bentuk dan konten oleh media-media komunikasi. Dengan banyaknya sumber informasi tersebut akan dapat memperkaya informasi dan pengetahuan bagi masyarakat. Bagi institusi, informasi sangat membantu dalam mencapai tujuan yang ditetapkan serta dalam proses pengambilan keputusan.

Bertambah banyaknya peran informasi di dalam kehidupan masyarakat modern, mengakibatkan kebutuhan akan tenaga-tenaga kerja yang memenuhi kualifikasi khusus yaitu yang menguasai teknologi informasi dan komunikasi juga semakin bertambah. Dengan adanya informasi dan tenaga kerja yang terampil akan mampu meningkatkan produktivitas kerja dan memberi prospek yang cerah bagi kemajuan industri.Informasi bagi suatu negara dapat sebagai sumber kekuasaan, dimana informasi merupakan alat ampuh untuk mengontrol penguasa. Selain itu informasi bagi suatu negara dapat memberi sumbangan kepada kekuatan dan kestabilan sistem sosial, politik, ekonomi dan kebudayaannya.

\section{f. Pengertian Era Informasi}

Pertemuan antara teknologi mutakhir dengan komputer melahirkan sebuah era baru, yakni era informasi. Era informasi merupakan sebuah era dimana melahirkan sebuah konsep global village (desa global). Globalisasi berasal dari kata golabal yang artinya secara umum 
atau keseluruhan. Era global adalah proses masuknya sebuah Negara keruang lingkup dunia, sehingga sekat-sekat (pembatas) antara Negara akan semakin kabur atau sering disebut dengan istilah borderless. Globalisasi biasanya ditandai dengan semakin majunya teknologi komunikasi, inilah yang disebut dengan era informasi (Marwah Daud Ibrahim, 1999). Collin Cherry (1980) mengatakan bahwa perkembangan teknologi komunikasi yang cepat disebabkan karena:

1. Secara potensial teknologi komunikasi dapat menjangkau hampir seluruh permukaan bumi hanya dalam tempo waktu yang sekejap.

2. Jumlah pesan dan arus lalu lintas informasi telah berlipat ganda.

3. Kompleksitas teknologi sendiri semakin lama semakin canggih.

Era globalisasi informasi memiliki potensi mengubah hampir seluruh sistem kehidupan masyarakat, politik, ekonomi, budaya dan sebagainya. Negroponte (1995) menjelaskan bagaimana era informasi telah mengubah model bisnis yang telah berkembang selama ini. Pada masa industri produk-produk berupa barang dibuat dalam bentuk materi yang memiliki wujud fisik. Namun pada era informasi produkproduk yang berkembang tidak lagi berupa fisik, tetapi bits. Bits atau sering disebut binary digit adalah materi yang tidak berwujud fisik, hanya berupa basis unit digital yang berupa bilangan 0 atau 1 (Mackenzie, 1980). Dengan berkembangnya produk yang tersusun atas bits, maka proses shipment atau pengiriman produk juga mengalami perubahan. Pada era industri setiap barang berbentuk fisik akan dikirim melalui pengiriman yang berbentuk fisik juga melalui jalur darat, laut, dan udara. Sedangkan produk hasil teknologi informasi yang tersusun atas bits dikirim melalui jalur telekomunikasi kabel atau nirkabel, sehingga biaya yang dibutuhkan lebih murah dengan waktu pengiriman yang lebih cepat dibadingkan produk fisik (Negroponte, 1995)

\section{g. Definisi E-Learning}

E-Learning atau Electronic Learning adalah intruksi atau perintah yang ditransmisikan melalui perangkat digital pengolah informasi seperti komputer, notebook, tablet, atau smartphone yang bertujuan untuk mendukung proses pembelajaran (Clark, Mayer, 2016). ELearning adalah sebuah implementasi dari metode Computer-Supported Collaborative Learning (CSCL) dalam bentuk sebuah aplikasi komputer. E-learning pada umumnya berbentuk aplikasi website dimana user atau pengguna sistemnya saling berinteraksi satu sama lain layaknya situs media sosial. User atau pengguna system yang dimaksud di sini tidak hanya peserta didik atau pendidik saja akan tetapi seluruh stakeholder dalam sebuah lembaga pendidikan.

Ada banyak definisi yang digunakan untuk menjelaskan apa itu e-learning. UNESCO mendifinisikan e-learning sebagai “...learning through available in the computers. Thus, E-learning or online learning is always connected to a computer or having information available through the use of computer". Sementara Lipshitz (2013) dalam bukunya "E-Learning: 21st Century Issues and Challenges"menjelaskan bahwa Elearning adalah: "A general term used to refer to computer-enhanced learning. It is used interchangeably in so many contexts that it is critical to be clear what one means when one speaks of 'E-learning"'. Selain definisidefinisi tersebut masih ada lagi definisi yang mendeskripsikan e-learning, akan tetapi semuanya memahami inti pemahaman yang sama yaitu suatu produk aplikasi komputer berbasis web yang digunakan untuk proses belajar mengajar. 
h. Media Pendidikan Berbasis ELearning

Implementasi e-learning sebagai media pendidikan sudah lumrah diterapkan di beberapa negara. Berdasarkan laporan Ambient Insight Comprehensive (2011) menyatakan bahwa rates pertumbuhan aplikasi e-learning di beberapa negara berkembang sesuai dengan data pada Tabell berikut:

Tabel 1. Data Pertumbuhan E-learning

\begin{tabular}{lc}
\hline Negara & Tingkat pertumbuhan \\
\hline India & $55 \%$ \\
China & $52 \%$ \\
Malaysia & $41 \%$ \\
Romania & $38 \%$ \\
Poland & $28 \%$ \\
Czech Republic & $27 \%$ \\
Brazil & $26 \%$ \\
Indonesia & $25 \%$ \\
Columbia & $20 \%$ \\
\hline
\end{tabular}

Masih menurut data yang sama pasar elearning dunia mencapai revenue sebesar \$32.1 milyar pada tahun 2010, dengan rate pertumbuhan revenue 5 tahunan sebesar 9,7\%maka pada tahun 2015 pertumbuhan revenue diperkirakan mencapai $\$ 49.9$ milyar.Sebuah rate pertumbuhan yang cukup besar apabila dibandingkan dengan tingkat pertumbuhan ekonomi suatu negara berkembang.

Data-data tersebut menunjukan bahwa penggunaan e-learning sebagai media pendidikan memang mengalami perkembangan yang signifikan dari tahun ke tahun. Indonesia sebagai salah satu negara berkembang tingkat pertumbuhan penggunaan aplikasi e-learning masih dibawah beberapa negara berkembang lainnya di dunia. Tingkat pertumbuhan penggunaan e-learning yang di bawah rata-rata ini disebabkan salah satunya oleh antusias masyarakat yang masih relatif rendah.

Ada beberapa alasan yang menyebabkan mengapa antusias masyrakat terhadap elearning masih relatif rendah, salah satu diantaranya adalah masyarakat belum begitu memahami manfaat yang akan dihasilkan melalui penggunaan media pembelajaran e-learning. Ada beberapa manfaat yang dapat dihasilkan dengan menggunakan media e-learning yaitu:

1. Memperjelas pesan/informasi agar tidak terlalu verbalistis.

2. Mengatasi keterbatasan jarak, ruang, dan waktu.

3. Dapat menimbulkan semangat belajar yang lebih baik karena peserta didik berinteraksi langsung dengan dengan sumber belajar.

Selain kelebihan-kelebihan tersebut, penggunan e-learning sebagai media pendidikan juga memiliki beberapa kelemahan. Kelemahan-kelemahan yang ada ini merupakan salah satu alasan juga yang melatar belakangi mengapa animo masyarakat terhadap media elearning masih rendah. Beberapa kelemahan tersebut antara lain:

1. Media e-learning bergantung pada teknologi komputer. Apabila infrastruktur teknologi komputer tidak bagus maka penggunaan e-learning juga tidak akan berjalan secara efektif.

2. Selain komputer mediae-learning juga membutuhkan koneksi internet. Kecepatan koneksi internet yang tidak memadai akan menghambat proses belajar mengajar melalui media elearning.

3. Penggunaan e-learning sebagai media pendidikan juga menuntut pemahaman akan IT yang cukup. Oleh karena itu kompetensi dasar di bidang IT merupakan syarat utama untuk menggunakan media e-learning dengan efektif. 
Penggunaan e-learning sebagai media pendidikan tidak hanya dikhususkan untuk peserta didik di level sekolah formal saja tetapi juga sering dimanfaatkan sebagai media training yang bersifat non-formal. Salah satu contohnya adalah penggunaan e-learning sebagai media training bagi para pekerja di suatu perusahaan atau organisasi-organisasi profit maupun nonprofit. Javari Navimipour dan Zareire (2015) dalam penelitiannya yang berjudul "A model for assessing the impact of e-learning" mengambil contoh kasus pada sebuah perusahaan telekomunikasi di Azerbaijan Timur dengan jumlah sampel sebanyak 240 orang. Sampel tersebut akan dinilai kemampuannya dalam memanfaatkan media e-learning melalui sebuah model penilaian yang ditawarkan oleh Javari Navimipour dan Zareire. Model penilaian tersebut dapat dilihat pada gambar 2 .

Dalam model penilaian yang diajukan tersebut didefinisikan 4 buah faktor yang mempengaruhi tingkat kepuasan penggunaan elearning yaitu Educational Technolgy,
Motivation, Educational Content, dan Attitude.

Empat buah faktor tersebut diuji terlebih dahulu dengan tujuan untuk mengetahui atau memastikan apakah empat buah faktor tersebut memang benar-benar memiliki efek yang mempengaruhi tingkat kepuasan pekerja dalam mengoperasikan media e-learning. Oleh karena itu beberapa buah metoda pengujian diterapkan pada model penilaian yang telah dirancang tersebut. Metode-metode pengujian tersebut antara lain Average Variance Extracted (AVE) untuk mengukur nilai Convergent Validity, Composite Realibility dan Cronbach's Alpha untuk mengukur nilai reliabilitas, serta Discriminant Validity untuk memastikan antara faktor satu dengan yang lain tidak saling memilik korelasi.

Melalui hasil pengujian terhadap komponen-komponen model penilaian yang telah dirancang tersebut dapat disimpulkan bahwa komponen-komponen yang diajukan memang benar-benar memiliki level signifikansi



Gambar 2. Model konseptual untuk menilai pengaruh e-learning pada tingkat kepuasan pekerja (Javari Navimipour, Zareire, 2015). 


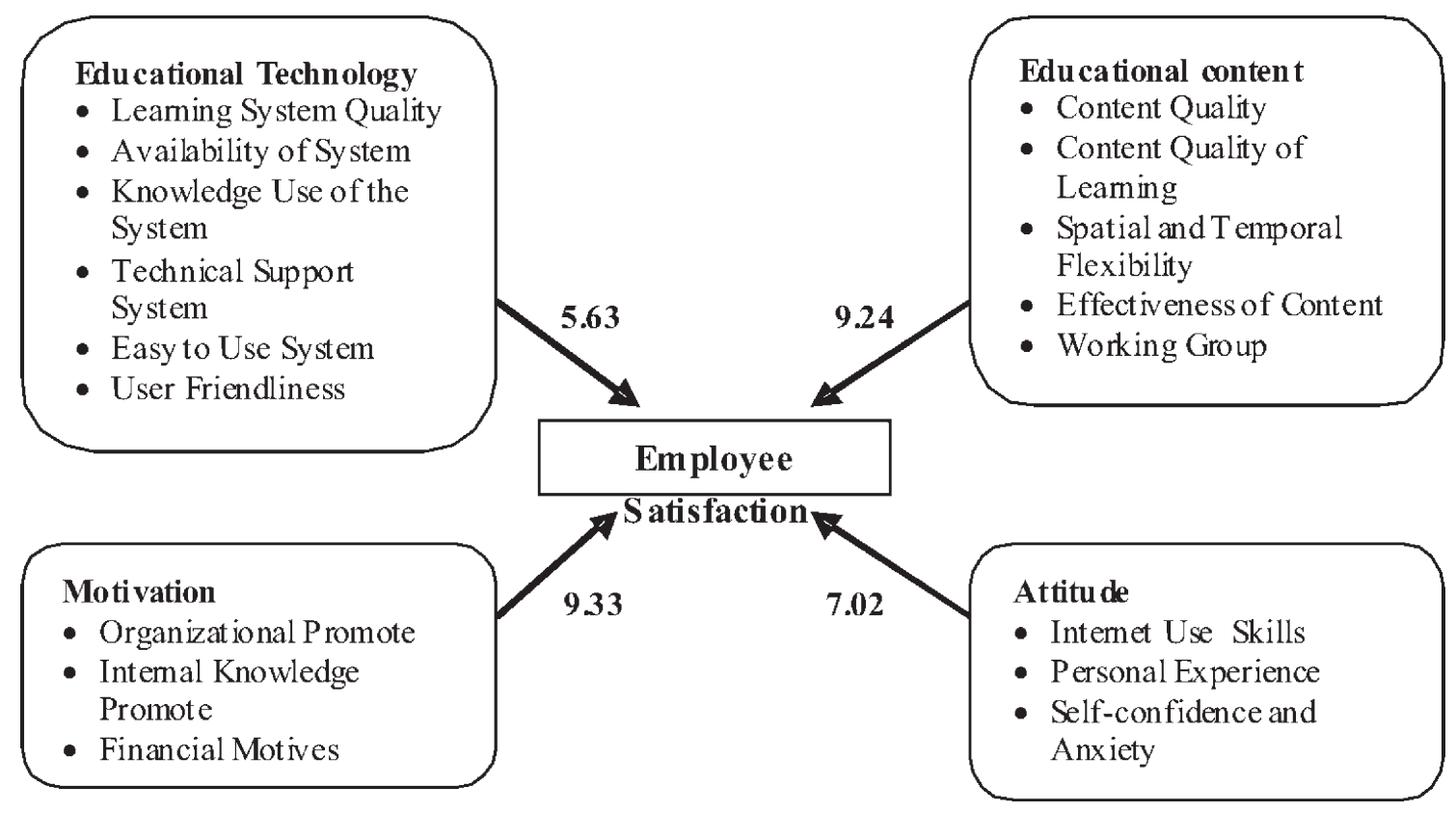

Gambar 3. Hasil T-result tingkat kepuasan pekerja dalam menggunakan media e-learning (Javari Navimipour, Zareire, 2015).

yang besar yang mempengaruhi tingkat kepuasan pekerja dalam memanfaatkan media e-learning. Setelah melakukan pengujian terhadap komponen-komponen penilaian, selanjutnya dilakukan pengujian untuk mengetahui apakah e-learning yang tersedia dapat meningkatkan tingkat kepuasan pekerja. Dengan menerapkan T-test diketahui bahwa para pekerja sangat puas terhadap kinerja dari media e-learning dan faktor yang memiliki pengaruh yang cukup signifikan adalah Motivation dan Educational content seperti yang ditunjukan pada gambar 3 .

Hasil penelitian tersebut memberikan informasi penting bahwa untuk memacu semangat peserta didik dalam memanfaatkan teknologi e-learning maka hal yang harus dipertimbangkan adalah motivasi dan konten atau materi ajar.Seorang peserta didik tidak mudah menerima begitu saja metode belajar yang baru atau asing apabila tidak memiliki motivasi yang kuat yang mendorongnya. Motivasi-motivasi tersebut dapat berupa alasan finansial, peningkatan status dalam organisasi, dan sejenisnya. Sementara faktor berikutnya yang sangat mempengaruhi adalah konten atau materi ajar. Agar dapat mudah dipahami oleh peserta didik, maka konten dalam e-learning harus dikemas semenarik mungkin. Konten yang dikemas dalam format multimedia (teks, audio, dan audio-visual) memiliki karakteristik yang lebih interaktif sehingga konten-konten dalam format multimedia lebih cepat dan lebih mudah untuk dipahami (Evans, Gibbon, 2006).

\section{SIMPULAN}

E-learning merupakan bagian dari metode belajar yaitu Metode Computer Supported Collaborative Learning (CSCL )pada era informasi yang menitikberatkan pada penggunaan komputer sebagai alat bantu. Teknologi e-learning menawarkan kemudahan proses belajar mengajar dimana kegiatan belajar mengajar tidak lagi terhalang oleh jarak, ruang dan waktu. Banyak negara di seluruh dunia yang telah memanfaatkan teknologi e- 
learning untuk meningkatkan kualitas pendidikan negara mereka ditunjukan dengan rate pertumbuhan pengguna teknologi elearning yang meningkat dari tahun ke tahun.

Penerapan teknologi e-learning di bidang masih menemui banyak hambatan diantaranya adalah faktor infrastruktur yang tidak siap, koneksi internet dan sumber daya manusia yang belum mumpuni dalam mengoperasikan teknologi e-learning. Namun berbagai hambatan tersebut tidak akan menjadi masalah yang besar apabila peserta didik memiliki motivasi yang sangat kuat untuk memanfaatkan teknologi ini. Semua hal dapat dipelajari dengan cepat dan mudah apabila peserta didik memiliki motivasi yang sangat kuat untuk mempelajarinya. Selain itu konten isi e-learning juga merupakan faktor penting selanjutnya. Penggunaan e-learning untuk membantu proses belajar mengajar tidak akan efektif apabila konten atau materi ajarnya susah dipahami oleh peserta didik. Konten yang bersifat interaktif akan lebih mudah untuk dipahami sehingga teknologi e-learning yang baik bukanlah teknologi yang harus canggih dan modern tetapi teknologi yang -user-friendly atau mudah untuk dioperasikan dan dipahami serta teknologi yang interaktif.

\section{DAFTAR PUSTAKA}

Alipandie, Imansyah, (1984), Didaktik Metode pendidikan. Surabaya : Usaha Nasional

Ambient Insight Comprehensive Report, (2011), The World Market for Self-paced eLearning Products and Services: 20102015 Forecast and Analysis, LLC.

Collin Cherry, (1980), On Human Communication, USA: The MIT Press.

Dewantara, K. H. (1994). Karya Ki Hadjar Dewantara bagian II : kebudayaan. Yogyakarta: Majelis Luhur Persatuan Tamansiswa.
Djamarah, Syaiful Bahri, (2000), Guru dan Anak Didik dalam Interaksi Edukatif. Jakarta:

Rineka Cipta

Evans, C, Gibbons, Nicola, J., (2007), The Interactivity Effect in Multimedia Learning, Computer and Education 49(4), 11471160

Floridi, Luciano, (2010), Information - A Very Short Introduction, Oxford University Press

Lipshitz, Audrey, R.,Parsons, Steven, (2013), E-Learning: 21st Century Issues and Challenges, Nova Science Publishers, Inc

Mackenzie, Charles E.,(1980), Coded Character Sets, History and Development. The Systems Programming Series (1 ed.), Addison-Wesley Publishing Company, Inc.

Nima Jafari Navimipou, Batool Zareie, (2015), A Model for Assessing the Impact of eLearning System on Employee's Satisfication, Computer in Human Behaviour (53), 475-485.

Hernandez-Seller, Nuria, GonzalesSanmamed, Mercedes, Munoz-Carril, Pablo Cesar, (2014), Planning Collaborative Learning in Virtual Environments, Comunicar Journal 42: Revolution in Education? (21).

Marwah Daud Ibrahim, (1999), Teknologi, Emansipasi dan Transendensi, Wacana Peradaban dengan Visi Islami, Bandung: Mizan,

Perry, William G. (1999). Forms of Ethical and Intellectual Development in the College Years. San Francisco: Jossey-Bass Publishers.

Philippe Aigon, Peter Howitt, Leonardo Bursztyn, (2009), The Economic of Growth, USA: The MIT Press 
Philip Stevens, Martin Weale, (2003), Education and Economic Growth, National Institute of Economic and Social Research (221).

The Philosophy of John Dewey Edited by John J. McDermott. University of Chicago Press, 1981.

Rasyidin.W, (2007), Pedagogik Teoritis dalam Ilmu dan Aplikasi Pendidikan, Bandung: Pedagogiana Press
Roestiyah,N.K., (2001), Strategi Belajar Mengajar, Jakarta : Rineka Cipta

Sukardjo M. (2009), Landasan Pendidikan Konsep dan Aplikasinya, Jakarta: Rajawali Pers

Vygotsky, Lev (1978). Mind in Society. London: Harvard University Press. 